\title{
Mewar Paintings: An exploratory study
}

\author{
SUDHA BABEL, RUPALI RAJVANSHI AND SANGEETA SHARMA
}

Received: 20.08.2014; Accepted: 22.11.2014

See end of the paper for authors' affiliations RUPALI RAJVANSHI Department of Textiles and Apparel Designing, College of Home Science, Maharana Pratap University of Agriculture and Technology, UDAIPUR (RAJASTHAN) INDIA
ABSTRACT : Mewar painting has its distinct and unique style whilst representing the hills, colours and palaces of Rajasthan. The objective of present study was to know about type of colours or pigments thickening or binding agents used for making different types of traditional painting of mewar and the problems faced by the artisans making different types of paintings. Thirty artisans were purposively selected for the purpose The results revealed that majority of the artisans were making paintings from more than a decade. Themes commonly used in Mewar paintings are based on Ramayana, Krishna Lila, Choura Panchasika, Ragamala series and Gita Govinda. The pigments used in paintings are sendur (Mercuric-Sulphide), Hinglu (Cinnabar-Mercuric Sulphide) Rav Sena (yellow-ochre), Jangal (verdigriscopper acetate), Safeda (Zinc White), Neel (Indigo), Geru (red ochre), Syahi(lamp Black),Asmani/ Lazvardi(lapis lazuli) and precious stones, conch shells, pure gold and silver. It took as long as several months to prepare the colours and prepare one painting, Only few artisans are using traditional method of preparing colour, new entrant in the field are using readymade colours. Problem faced by them were mainly related to eye irritation, pain at shoulder, back, fingers, wrist and skin allergy at hands.

KEY WORDS: Mewar paintings, Techniques, Pigments /colours used, Binders, Thickeners used

- HOW TO CITE THIS PAPER : Babel, Sudha, Rajvanshi, Rupali and Sharma, Sangeeta (2014). Mewar Paintings: An exploratory study. Asian J. Home Sci., 9 (2) : 636-640. 